Asian J. Med. Biol. Res. 2017, 3 (1), 88-93; doi: 10.3329/ajmbr.v3i1.32042

\author{
Asian Journal of \\ Medical and Biological Research \\ ISSN 2411-4472 (Print) 2412-5571 (Online) \\ www.ebupress.com/journal/ajmbr
}

\title{
Article \\ The effect of commercial probiotics on health and production of shrimp (Penaeus monodon)
}

\author{
Rubia Akter ${ }^{1}$, Md. Rayhan Hossain ${ }^{2}$, Md. Motiur Rahman ${ }^{1}$, B.M. Shahinur Rahman ${ }^{1}$ and K K U Ahmed ${ }^{1}$ \\ ${ }^{1}$ Shrimp Research Station, Bangladesh Fisheries Research Station Institute, Bagerhat-9300, Bangladesh \\ ${ }^{2}$ Bangladesh Fisheries Research Institute, Freshwater Station, Mymensingh -2201, Bangladesh
}

*Corresponding author: Rubia Akter, Shrimp Research Station, Bagerhat-9300, Bangladesh. Phone: +8801670043068; E-mail: rubiazaman@yahoo.com

Received: 05 March 2017/Accepted: 22 March 2017/ Published: 30 March 2017

\begin{abstract}
The study was carried out to explore the impact of probiotics on shrimp (Penaeus monodon) in the Shrimp Research Station ponds during the culture period of 90 days. The experiment was set in 9 on-station ponds having an area of $0.052-0.064$ ha. Three treatments of the experiment were: super Ps probiotics broadcast all over the ponds mixed with clay $\left(\mathrm{T}_{1}\right)$, probiotics broadca Zymetin st over the pond mixed with feed $\left(T_{2}\right)$ and control (without probiotics) the ponds $\left(T_{3}\right)$ and each treatments having 3 replicates. All Juvenile of shrimp were stocked at a density of $6.0 \mathrm{juv} / \mathrm{m}^{2}$ and was fed with quality feed (gold plus-grower) twice daily at the rate of $10.3 \%$ of shrimp biomass. Water quality parameters namely temperature, water depth, dissolved oxygen, $\mathrm{pH}$, salinity, ammonia, nitrate, total alkalinity and transparency were within suitable range for shrimp growth without finding any stress. Growth of shrimp was measured and feed was adjusted after every fortnight. The average weight of shrimp in $\mathrm{T}_{1}, \mathrm{~T}_{2}$ and $\mathrm{T}_{3}$ was $22.065 \pm 5.52,19.87 \pm 4.98$ and $11.01 \pm 0.86 \mathrm{~g}$, respectively. Higher growth was obtained from $\mathrm{T}_{1}$ followed by $\mathrm{T}_{2}$ and $\mathrm{T}_{3}$. Day after 90 of husbandry, all shrimp were harvested. The survivality rate of shrimp production was reckoned $80 \%$. The production of shrimp was found $760 \mathrm{~kg} / \mathrm{ha}$ in $\mathrm{T}_{1}, 665 \mathrm{~kg} / \mathrm{ha}$ in $\mathrm{T}_{2}$ and $205.19 \mathrm{~kg} / \mathrm{ha}$. in $\mathrm{T}_{3}$. So the highest production was found using super PS $\left(\mathrm{T}_{1}\right)$. Food conversion ratio (FCR) of prawn was found higher (2.48) in $\mathrm{T}_{3}$ compared to $\mathrm{T}_{1}(1.83)$ and $\mathrm{T}_{2}(2.01)$. The result of the study is therefore revealed that probiotics paly a most important role in growth, survival and production of shrimp by maintaining good water quality environment throughout the culture period. It may be therefore concluded that probiotics can be utilized well the shrimp ponds to get higher growth and production keeping the congenial environment.
\end{abstract}

Keywords: probiotics; production; Penaeus monodon; growth

\section{Introduction}

Fisheries and aquaculture are making crucial contributions to the world's wellbeing and prosperity (FAO, 2012). Aquaculture, directly or indirectly, play an essential role in the livelihoods and income of millions of people, particularly in developing countries. It has been increasingly proved as an important source of animal protein for the world`s growing population.

Bangladesh is considered to be one of the most suitable countries in the world for brakishwater shrimp (Penaeus monodon) farming due to its fertile land and agro-climatic conditions. Brakishwater shrimp (Penaeus monodon) is wide cultured due to its advantages over other in terms of size, growth, salinity tolerance and high price in international markets. It is a highly valued product for international markets particularly to the USA, Europe and Japan. The export of prawn and shrimp was estimated at 50,368 $\mathrm{mt}$ in 2008-09 with a value of 2,744.12 crore of which 27-30\% was galda (DOF 2010). The export of prawn and shrimp was estimated at 50,368 mt in 2008-09 with a value of 2,744.12 crore of which 27-30\% was galda (DOF 2010). The production of it gradually increases in Bangladesh shrimp (Penaeus monodon) and other countries of the world. Farmers of the coastal areas are 
provided more attention on prawn farming because of its more disease resistant capability than other shrimp has significant aquaculture potential and also as commercially cultured (Muir 2003). Currently the critical issues of prawn/shrimp farmers is soil-water management of farm and the volume of organic sludge created within the pond during culture periods and later is released into surrounding water bodies. Use of probiotics in aquaculture is increasing with the demand for more environment friendly aquaculture practices (Gatesoupe, 1999). Probiotics in aquaculture can be administrated either as a food supplement or as a additive to the water (Moriarty, 1998). Though several types of probiotics (Aqua photo, Aqua mazic, Ammonil, Super biotic, Super P S) in powder or liquid forms are found in the markets, most of the farmers don't know the uses and impacts of these probiotics. Very little information is available in Bangladesh regarding soil-water quality and production improvement of prawn after using of probiotics. The successful implementation of the study can help to increase national production and earnings, spread sustainable shrimp farming technology, improve skill of shrimp farmers, open new arena of sustainable research to the researcher.

\section{Materials and Methods}

\subsection{Study place and time}

Nine rectangular ponds of Shrimp Research Station (SRS), Bangladesh Fisheries Research Institute, Bagerhat were used for the experiment. One tidal river, Doratana flows by the side of the research station. The central out let of the research ponds is directly connected with this river through a canal. Size of the culture ponds is around $0.052-0.064$ ha. The study was carried out from April to July 2015.

\subsection{Experimental design}

Three treatments of the experiment were: super Ps probiotics broadcast all over the ponds mixed with clay $\left(\mathrm{T}_{1}\right)$, super biotic probiotics broadcast over the pond mixed with feed $\left(\mathrm{T}_{2}\right)$ and control (without probiotics) the ponds $\left(\mathrm{T}_{3}\right)$ and each treatments having 3 replicates in Table 1.

Table 1. Experimental design of the present study.

\begin{tabular}{lllll}
\hline \multirow{2}{*}{ Treatments } & Replication & $\begin{array}{l}\text { Stocking } \\
\text { density } \\
\text { (No./ha) }\end{array}$ & Probiont type & \multicolumn{2}{c}{ Application of probiotics } \\
\cline { 4 - 5 } & 3 & 60,000 & $\begin{array}{l}\text { Super PS Probiotics broadcast on } \\
\text { the pond }\end{array}$ & $\begin{array}{l}\text { Every 10 days Intervals } \\
(15 \text { liter/ha) }\end{array}$ \\
$\mathrm{T}_{1}$ & 3 & $\begin{array}{l}\text { Zymetin Probiotics broadcast on } \\
\text { the pond }\end{array}$ & 3kg/week/ha \\
$\mathrm{T}_{2}$ & 3 & 60,000 & Feed without probiotics & -- \\
$\mathrm{T}_{3}($ Control $)$ & 3 & 60,000 & &
\end{tabular}

\subsection{Pond preparation and water management}

The pond was first dewatered with pump and dried under sun light for one month to excavate the bottom mud and to do digging of the experimental ponds; thus automatically aquatic weed and unexpected fauna was removed. The embankment of the pond was repaired and constructed. Liming was done after 2-3 days of drying. Calcium carbonate $\left(\mathrm{CaCO}_{3}\right)$ and/or dolomite were used as a liming agent. After testing $\mathrm{PH}$, liming was done at a dose of $1 \mathrm{~kg} /$ decimal that helps to maintain good water quality. Watering was done after liming. The pond was filled up with water up to a depth of about 1.5 meter.

\subsection{Fencing}

The total area of the ponds was fenced so that undesirable organisms cannot enter the pond from outside. Thus it was protected from predator and other undesirable fishes, amphibians, reptiles, insects, frogs etc.

\subsection{Sanitizing}

Bushes on the banks of the ponds were removed manually to destroy the habitat of other predators like otters, snakes, etc.

\subsection{PL Nursing and stocking}

After pond preparation, PL nursing was done in the pond for 20 days for shrimp and 40 days for Prawn to reach the PL into juvenile to reduce the mortality rate of prawn and shrimp into the grow-out pond. 
2.7. Feed and feeding management

In these experiments MEGA supplementary feed was used in the ponds. In first one month, feed was given at $10 \%$ of fish body weight, then three months at $5 \%$ of fish body weight, and last months the rate was $2 \%$ of the total Shrimp body weight. In this study feeding was given three times in a day, in $7.00 \mathrm{am}, 12.00 \mathrm{pm}$ and 6.00 pm respectively.

\subsection{Prawn sampling}

Number of 100 shrimp from each pond was sampled for two times in a month.

\subsection{Growth measurements}

The total length $(\mathrm{cm})$, body weight $(\mathrm{g})$, of shrimp was measured at every fifteen days interval.

\subsection{Water quality parameters determination}

Most of the water quality parameters $\mathrm{pH}$, DO, Carbon dioxide $(\mathrm{CO} 2)$, alkalinity, ammonia and nitrite was measured by using $\mathrm{HACH}$ Kit, produced by $\mathrm{HACH}$, USA (Model FF-2) and also using specific parameters measuring equipment.

\subsection{Microbial analysis}

Fortnightly/monthly quantity of total heterotrophic bacteria (THB) and pathogenic bacteria (Vibrio spp.) of pond water and sediment was monitored. These were compared with controlled ponds (without probiotics). Microbial analysis was done to identify bacterial quality of the treatments. The laboratory tests were done in the Disease Lab of Shrimp Research Station, Bagerhat.

\subsection{Zymetin}

Zymetin is made with beneficial bacteria used in feed. It is usually mixed with feed to increase immunity and inhibit the growth of pathogenic bacteria in the gut. It also improves the appetite of the shrimp and increase function of digestion and assimilation for better growth and reduces FCR. It is composed mainly with Streptococcus faecalis, Clostridium butyricum, Bacillus mesentericus, Protease, Lipase and Beer yeast.

\subsection{Super PS}

Super PS is a soil probiotics made with beneficial bacteria which is used to improve pond bottom condition, reduce harmful bacteria and keep the environment friendly for aquaculture. It is composed mainly with Rhodobacter spp. and Rhodococcus spp.

\subsection{Shrimp haemocyte analysis}

An electric microscope and clinical haemocytometer was used for differential counts of prawn and shrimp haemocytes following the method of Owens \& O`Neill`s (1997) with some modifications.

\subsection{Statistical Analysis}

Microsoft Excel and One-way analysis of variance (ANOVA) was used to determine any significant differences among the treatments using SPSS 16 software.

\section{Results and Discussion}

\subsection{Bacterial load}

A selected probiotics such as super PS is applied at 15 liter/ha and Zymetin is used at 3kg/week/ha in the ponds under treatment 1 and 2. The artificially manufactured probiotics (beneficial bacteria), Bacillus spp. comprising strength of $\pm \mathrm{CFU} / \mathrm{g}$ (recommended by manufacturer) is administered in the ponds. The population of total heterotrophic bacteria (THB) of pond waters and sediments is estimated on monthly intervals. Bacterial floras present in ponds are analyzed and it is found that bacterial load in water and sediment ranged from $2.90 \times 10^{4}-$ $3.76 \times 10^{4} \mathrm{CFU} / \mathrm{ml}$ and $2.63 \times 10^{4}-3.15 \times 10^{4} \mathrm{CFU} / \mathrm{gm}$ in $\mathrm{T}_{1}, 2.80 \times 10^{3}-3.54 \times 10^{3} \mathrm{CFU} / \mathrm{ml}$ and $3.97 \times 10^{4}-$ $3.17 \times 10^{4} \mathrm{CFU} / \mathrm{gm}$ in $\mathrm{T}_{2}$ and $2.28 \times 10^{4}-3.11 \times 10^{4} \mathrm{CFU} / \mathrm{ml}$ and $2.31 \times 10^{4}-3.21 \times 10^{4} \mathrm{CFU} / \mathrm{gm}$ in $\mathrm{T}_{3}$, respectively in Table 2 \& Figure 1. 
Table 2. Quantitative profile of THB in waters and sediments of ponds.

\begin{tabular}{lll}
\hline Treatments & & Bacterial load (CFU/ml and CFU/gm) \\
\hline $\mathrm{T}_{1}$ & Water & $2.90 \times 10^{4}-3.76 \times 10^{4}$ \\
& Soil & $2.63 \times 10^{4}-3.15 \times 10^{4}$ \\
$\mathrm{~T}_{2}$ & Water & $2.80 \times 10^{4}-3.54 \times 10^{4}$ \\
& Soil & $2.97 \times 10^{4}-3.17 \times 10^{4}$ \\
$\mathrm{~T}_{3}$ & Water & $2.28 \times 10^{4}-3.11 \times 10^{4}$ \\
& Soil & $2.31 \times 10^{4}-3.21 \times 10^{4}$ \\
\hline
\end{tabular}

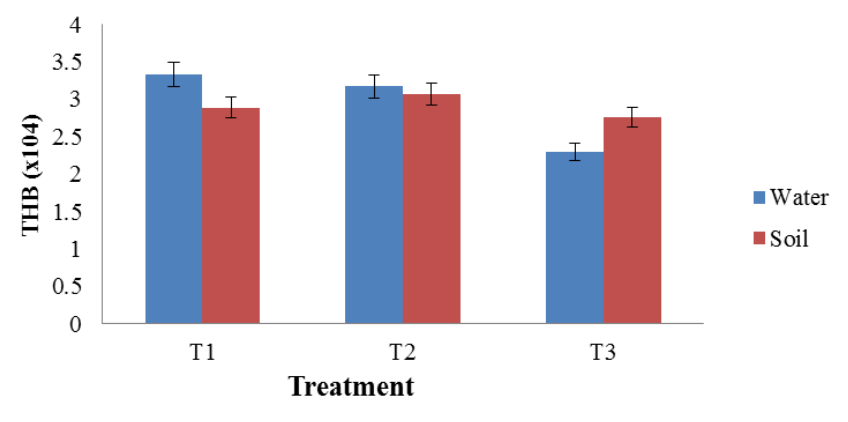

Figure 1. Quantitative estimation of THB in water and soil of pond (April-June, 2015).

Probiotics is used in aquaculture and its production systems to modify the micirobial population of the environment ultimately achieving better growth and survival of the targeted species. Even nonpathogenic strains of pathogenic bacteria are being used as probiotics in shrimp culture. (Vijayakumaran, 2001)

Super PS was labeled with containing Rhodobacter sp. and Rhodococcus sp. However, in this study, both of the commercial probiotics were supplied to increase beneficial in prawn gut and also in soil and water. Among the supplied beneficial bacteria, Streptococcus faecalis was identified and counted after culturing in selective media. The number of beneficial bacteria found in the soil and water was $2.90 \times 10^{4}-3.76 \times 10^{4} \mathrm{CFU} / \mathrm{ml}$ and $2.63 \times 10^{4}-3.15 \times 10^{4} \mathrm{CFU} / \mathrm{gm}$ in $\mathrm{T}_{1}, 2.80 \times 10^{3}-3.54 \times 10^{3} \mathrm{CFU} / \mathrm{ml}$ and $3.97 \times 10^{4}-3.17 \times 10^{4} \mathrm{CFU} / \mathrm{gm}^{2}$ in $\mathrm{T}_{2}$ and $2.28 \times 10^{4}-3.11 \times 10^{4} \mathrm{CFU} / \mathrm{ml}$ and $2.31 \times 10^{4}-3.21 \times 10^{4} \mathrm{CFU} / \mathrm{gm}$ in $\mathrm{T}_{3}$, respectively. Very less amount beneficial bacteria found in control compared to probiotics treated pond.

\subsection{Water quality monitoring}

Different water quality parameters (temperature, water depth, dissolved oxygen, $\mathrm{pH}$, salinity, ammonia, nitrate, total alkalinity and transparency) are measured at weekly intervals. Remarkable variations in parameters were not found among the different treatments. Water quality parameters of different ponds in Table 3.

Table 3. Water quality parameters (mean \pm SD) of the ponds.

\begin{tabular}{llll}
\hline \multirow{2}{*}{ Parameters } & \multicolumn{1}{c}{ Treatments } \\
\cline { 2 - 4 } & $\mathbf{T}_{\mathbf{1}}$ & $\mathbf{T}_{\mathbf{2}}$ & $\mathbf{T}_{\mathbf{3}}$ \\
\hline Temperature $\left({ }^{\circ} \mathrm{C}\right)$ & $27.42 \pm 1.27$ & $27.0 \pm 1.25$ & $27.20 \pm 1.30$ \\
Salinity $(\mathrm{ppt})$ & $4.7 \pm 0.50$ & $4.5 \pm 0.32$ & $4.2 \pm 0.25$ \\
$\mathrm{DO}(\mathrm{mg} / \mathrm{L})$ & $5.78 \pm 0.34$ & $5.25 \pm 0.36$ & $5.08 \pm 0.22$ \\
$\mathrm{pH}$ & $7.9 \pm 0.35$ & $7.5 \pm 0.25$ & $7.3 \pm 0.19$ \\
$\mathrm{NO}_{2}-\mathrm{N}(\mathrm{mg} / \mathrm{L})$ & $0.001 \pm 0.0009$ & $0.001 \pm 0.0005$ & $0.001 \pm 0.0005$ \\
$\mathrm{NH}_{4}-\mathrm{N}(\mathrm{mg} / \mathrm{L})$ & $0.17 \pm 0.005$ & $0.16 \pm 0.005$ & $0.16 \pm 0.005$ \\
Total alkalinity $(\mathrm{mg} / \mathrm{L})$ & $97.00 \pm 11.13$ & $96.5 \pm 11.20$ & $100.00 \pm 18.26$ \\
Transparency $(\mathrm{cm})$ & $34.00 \pm 4.69$ & $36.5 \pm 5.80$ & $36.3 \pm 4.27$ \\
Temperature $\left({ }^{\circ} \mathrm{C}\right)$ & $27.42 \pm 1.27$ & $27.0 \pm 1.25$ & $27.20 \pm 1.30$ \\
\hline
\end{tabular}


The maintenance of good water quality is essential for both survival and optimum growth of culture organisms. During the study period, the water quality parameters were within the suitable range (Annexturel). The optimum range of $\mathrm{pH} 7.0$ to 8.5 should be maintained for maximum growth and production (New, 2002 and Knowlton et al., 1984). In this study, the $\mathrm{pH}$ of the all control and treated ponds was ranged from 7.55 to 7.87 , it resembles within the recommended optimistic range which is best for the growth of Macrobrachium rosenbergii (New, 2002; Knowlton et al., 1984).

Water temperature is probably the most important environmental variables in prawn cultures, because it directly affects metabolism, oxygen consumption, growth moulting and survival. The optimum temperature range for year-round production should be between 25 and $31^{\circ} \mathrm{C}$, but best results can be achieved if the water temperatures remain between 28 and $31^{\circ} \mathrm{C}$ (New, 2002). Increase in temperature beyond $28-31^{\circ} \mathrm{C}$, increases the metabolic function which consecutively increases the growth rate. The temperature in the present study was 28 to $31^{\circ} \mathrm{C}$ during August to November that supports high growth rate in this study although the low temperature $20^{\circ} \mathrm{C}$ was observed during December in an unexpected weather when winter's cold-wind was blowing. The optimum dissolved oxygen (DO) content of fresh water prawn pond waters should be in the range of 3-7 ppm saturation level (New, 2002). For each $\mathrm{kg}$ of added feed (20-40\% crude) protein, approximately $30 \mathrm{~g}$ of total ammonia are released in the water (Boyd and Tucker, 1998)

Sakkaravarthi et al. (2010) evaluated the differences between regular and irregular application of soil probiotics in the p. momodon shrimp farming and found that level of ammonia found nil for the entire culture period in the regularly probiotics used ponds whereas it was $0.3 \mathrm{mg} / \mathrm{L}$ in irregularly treated pond. The present study showed that non ionized ammonia was within the range all over the culture period.

\subsection{Growth, survival and production performance}

Growth of shrimp was measured and feed was adjusted after every fortnight. On 6th July/2015, the average weight of shrimp in $\mathrm{T}_{1}, \mathrm{~T}_{2}$ and $\mathrm{T}_{3}$ was $22.065 \pm 5.52,19.87 \pm 4.98,11.01 \pm 0.86$ gm respectively. From the collected data so far, it can be mention that the highest production was found using Super PS.

Table 4. Growth survival and production (mean \pm SD) of (Penaeus monodon) in different treatments during the culture period.

\begin{tabular}{llll}
\hline Particulars & \multicolumn{3}{c}{ Treatments } \\
\cline { 2 - 4 } & $\mathbf{T}_{\mathbf{1}}$ & $\mathbf{T}_{\mathbf{2}}$ & $\mathbf{T}_{\mathbf{3}}$ \\
\hline Stocking density $\left(\mathrm{no} . / \mathrm{m}^{2}\right)$ & 6 & 6 & 6 \\
Stocking size $(\mathrm{g})$ & 0.025 & 0.025 & 0.025 \\
Harvesting size $(\mathrm{g})$ & $19.43 \pm 0.42^{\mathrm{b}}$ & $22.18 \pm 0.35^{\mathrm{a}}$ & $11.25 \pm 0.25^{\mathrm{c}}$ \\
Survival & $72.37 \pm 0.25^{\mathrm{a}}$ & $62.20 \pm 0.66^{\mathrm{b}}$ & $48.04 \pm 0.37^{\mathrm{c}}$ \\
FCR & 1.83 & 2.01 & 2.48 \\
Production $(\mathrm{kg} / \mathrm{ha})$ & $751.20 \pm 3.26^{\mathrm{a}}$ & $663 \pm 0.71^{\mathrm{b}}$ & $205.50 \pm 0.50^{\mathrm{c}}$ \\
\hline
\end{tabular}

Figures with different superscripts in the same row differ significantly $(p<0.01)$

In case of (Penaeus monodon), Bacillus, used as a production was able to colonize both the culture water and shrimp digestive tract, Bacillus also was able to replace vibrio spp. In the gut of shrimp, thereby increasing shrimp survival (Rengpipat et al., 1998). Bacillus is able to out-compete other bacteria for nutrients and space and can exclude other bacteria through the production of antibiotic (Verschuere et al., 2000; Moriarty, 1998). In this study Super PS was applied in T1 where observed significant increment in growth including improved feed conversion ratio (FCR) which in turn contributed to the improved survival rate of shrimp.

\subsection{Shrimp haemocyte analysis}

The total haemocytes counts (THC) were $10,240 \mathrm{cmm}, 9,600 \mathrm{cmm}$ and $8000 \mathrm{cmm}$ in T1, T2 and control respectively. The total haemocytes number was little bit less in the shrimp blood of control pond where probiotic was not supplied in Table 5.

Table 5. Total haemocyte count of shrimp blood.

\begin{tabular}{ll}
\hline Treatments & THC/cmm (cubic millimeter) \\
\hline $\mathrm{T}_{1}$ & $10,240 \mathrm{cmm}$ \\
$\mathrm{T}_{2}$ & $9,600 \mathrm{cmm}$ \\
$\mathrm{T}_{3}$ & $8000 \mathrm{cmm}$ \\
\hline
\end{tabular}




\section{Conclusions}

Probiotics play vital role to increase survival rate, enhance growth, reduce pathogen, keep the culture environment friendly, and thus farmers would ultimately get higher production and economic return. In recent times, bacterial diseases are considered to be a major threat in prawn culture. Thus, there is clearly a need to increase knowledge to combat the harmful pathogen eco-friendly. Moreover, numbers of manufacturer and sellers importing different branded probiotics, unfortunately farmers using them imprudently, but before using them in the country, it necessitate extensive research form independent research organizations not from importer of producer. However, the findings of this study could be applied extensively to the farmer's level to increase the production of shrimp in country.

\section{Acknowledgements}

The author wishes to his profound sense of gratitude sincere appreciation and indebtedness to his respected chief scientific officer K K U Ahmed, Shrimp Research Station, Bangladesh Fisheries Research Station Institute, Bagerhat-9300 for his scholastic guidance, valuable suggestions, affectionate feelings, constant encouragement and constructive criticisms and over all supervision throughout the study.

\section{Conflict of interest}

None to declare.

\section{References}

Austrand M and F Vidal, 1995. An alternative technology for shrimp larval rearing. Fish.-chimes, 15: 15-17.

Barrow GI and RKA Feltham, 1993. Cowan and Steel's manual for the identification of medical bacteria $\left(3^{\text {rd }}\right.$ Edition). Cambridge University Press, Cambridge, UK. p. 331.

Boyd CE and CS Tucker, 1998. Pond Aquaculture Water Quality Management. Kluwer Academic Publishers, USA.

Dalmin GK, Kathiresan and A Purushothaman, 2001. Effect of probiotics on bacterial population and health status of shrimp in culture pond ecosystem. Indian J. Exp. Biol., 39: 939-42.

DFO (Department of Fisheries), 2010. Exported fish and fisheries by product of Bangladesh. Department of Fisheries, Ministry of Fisheries and Livestock, Dhaka, Bangladesh. 107 p.

Dixon B, 1993. Special session marine fish: Microbiology in commercial hatcheries. Oostende-Belgium European-Aquaculture-Soc, 19:301.

FAO 2012. The State of World Fisheries and Aquaculture 2012. FAO Fisheries and Aquaculture Department, Food and Agriculture Organization of the United Nations, Rome.

Gatesoupe FJ, 1991. The use of probiotics in fish hatcheries: results and prospects. International Counc. for the Exploration of the Sea, Copenhagen (Denmark), Mariculture Comm. Copenhagen, Denmark, ICES. 7 pp.

Gatesoupe FJ, 1999. The use of probiotics in aquaculture. Aquaculture, 180:147-165.

Gilberg AH, E Mikkelsen, Sandaker and E Ringoe, 1997. Probiotic effect of lactic acid bacteria in the feed on growth and survival of fry of Atlacti cod (Gadus morhua). Hydrobiologia, 352: 279-285.

Moriarty DJW, 1998. Control of luminous Vibrio species in paneid aquaculture ponds. Aquaculture, 164: 351358.

Muir JF, 2003. The future for fisheries: economic performance. Fisheries Sector Review and Future Development Study. Commissioned with the association of the World Bank, DANIDA, USAID, FAO, DFID with the cooperation of the Bangladesh Ministry of Fisheries and Livestock and the Department of Fisheries, Dhaka, 172 pp.

New MB, 2002. Farming fresh water prawns: a manual for the culture of the Giant River prawn (Macrobrachium rosenbergii), FAO, Rome. 13p,212p. (FAO Fisheries Technical Paper, 428). C.

Ringoe E and FJ Gatesoupe, 1998. Lactic acid bacteria in fish: a review. Aquaculture, 3: 177-203.

Pal HK, MS Islam and MJ Alam, 2010. Effect of a commercial probiotics (Bacillus sp.) on brackishwater shrimp. Bangladesh J. Agri., 35: 127-133.

Rengpipat S, W Phianpahak, S Piyatiratitivorakul, P Menasveta, 1998. Effect of probiotics bacterium on black tiger shrimp Penaeus monodon survival and growth. Aquaculture, 167: 301-313

Sakkaravarthi K, G Sankar, K Ramamoorthy and R Lakshmanan, 2010. Effect of soil probiotics in the shrimp culture, International Journal of Bioflus soceity, ABAH Bioflus 2010, 299-105.

Sambashivam AR, Chandran and SA Khan, 2003. Role of probiotics on the environment of shrimp pond. J. Environ. Biol., 24:103-106.

Verschuere L, G Rombaut, P Sorgeloos and W Verstrate, 2000. Probiotic bacteria as biological control agents in aquaculture. Microbiology and Molecular Biology Review, 64: 655-671.

Vijayakumaran M, 2001. Probiotics in aquaculture, Perspectives in mariculture, 369:103-108. 